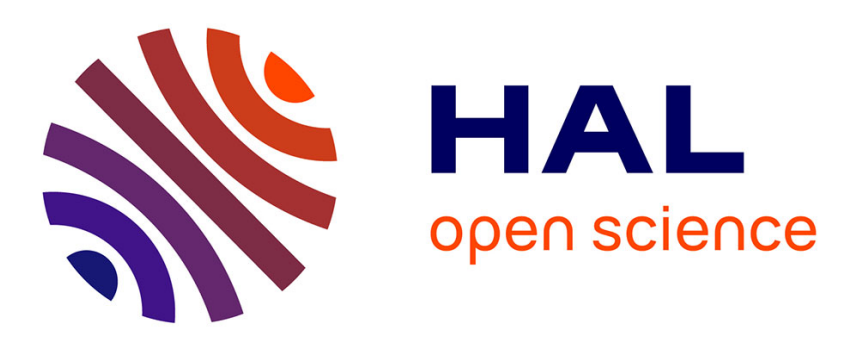

\title{
Muscle pigmentation changes during and after spawning in male and female rainbow trout Oncorhynchus mykiss fed dietary carotenoids
}

Georges Choubert, J.M. Blanc

\section{- To cite this version: \\ Georges Choubert, J.M. Blanc. Muscle pigmentation changes during and after spawning in male and female rainbow trout Oncorhynchus mykiss fed dietary carotenoids. Aquatic Living Resources, 1993, 6 (2), pp.163-168. hal-02700045}

\section{HAL Id: hal-02700045 \\ https://hal.inrae.fr/hal-02700045}

Submitted on 1 Jun 2020

HAL is a multi-disciplinary open access archive for the deposit and dissemination of scientific research documents, whether they are published or not. The documents may come from teaching and research institutions in France or abroad, or from public or private research centers.
L'archive ouverte pluridisciplinaire $\mathbf{H A L}$, est destinée au dépôt et à la diffusion de documents scientifiques de niveau recherche, publiés ou non, émanant des établissements d'enseignement et de recherche français ou étrangers, des laboratoires publics ou privés. 


\title{
Muscle pigmentation changes during and after spawning in male and female rainbow trout, Oncorhynchus mykiss, fed dietary carotenoids
}

\author{
Gcorges Choubert ${ }^{(1)}$ and Jean-Marie Blanc ${ }^{(2)}$ \\ (1) INRA, Laboraloire de Nutrition des Poissons, \\ (2) INRA, Laburaloire d'Amélioration des Poecilolhermes, \\ Station d'Hydrobiologie, B.P. 3, 643ro Saint-P'e-sur-Vivelle, Irance. \\ Reccived Septemler 14, rg92; accepted March 29, 1993.
}

\begin{abstract}
The dynamics of astaxanthin and canthaxanthin were studied through an 11-month feeding experiment by following carotenoid deposition in male and female rainbow trout muscle, during and after spawning. Carotenoids were analysed by chromatography (HPLC), muscle colour was measured by a colourimeter and visual rank evaluation. In both sexes, a decrease in the muscle carotenoid content was observed at spawning timc. The recovery of the muscle pigmentation differed between females and males, but seemed not to be influenced by the type of carotenoid additives in feed. The carotenoid content of the female muscle increased rapidly after spawing, while in the male this increase was slower. Eighteen weeks after spawing, carotenoid concentrations in the muscle of femalcs corresponded to those before spawning, while in males they reached only one third of that amount. Significant correlations were found between chemical analysis, colourimetric measurements and visual rank evaluation.
\end{abstract}

Choubert G., J.-M. Blanc. Aquat. Lizing Resour., 1993, 6, 163-168.

Keywords: carotenoid, pigmentation, colour, spawning season, trout.

Modifications de la pigmentation musculaire, lors de la reproduction, chez le mâle et la femelle de truite arc-en-ciel, Oncorhynchus mykiss, recevant un aliment supplémenté caroténoïdes.

Résumé

Les dynamiques de fixation de l'astaxanthine et de la canthaxanthine ont été suivies, pendant et après la période de reproduction, dans le muscle de truites mâles et femelles. La durée de l'expérience a été de 11 mois. Les caroténoïdes ont été analysés par chromatographie (HPLC), la couleur du muscle a été mesurée à l'aide d'un colorimètre et d'un test de rang. Pour les deux sexes, on a observé une diminution de la concentration en caroténoïdes du muscle au moment de la ponte. La reprise de pigmentation a été différente chez les mâles et chez les femelles, mais ne semble pas avoir été influencée par les caroténoïdes alimentaires. Alors que, chez les femelles, l'augmentation des caroténoïdes musculaires s'est faite juste après la pontc, chez les mâles, cette reprise a été plus lente. Dix-huit semaines après la ponte, les concentrations en caroténoïdes des femelles correspondaient à celles observées avant la ponte; chez les mâles, ces concentrations n'atteignaient que le tiers. Des corrélations significatives ont été trouvées entre l'analyse chimique, la mesure de la couleur et le test de rang.

Mots-clés : caroténoïdes, pigmentation, couleur, reproduction, truite. 


\section{INTRODUCTION}

Because salmonids-salmon and trout-cannot synthesize carotenoids de noro, they must obtain them from their diet. In the wild, salmonids obtain most of their carotenoids by feeding on small crustaceans and other invertebrates. In intensively farmed fish the aquatic environment does not contribute sufficient carotenoids. These must be supplied as compounds produced by synthesis and added to the diet to mect the animal's requirement. Today, astaxanthin $\left(3,3^{\prime}-\right.$ dihydroxy-4, $4^{\prime}$-diketo- $\beta, \beta$-carotene) and canthaxanthin $\left(4,4^{\prime}\right.$-diketo- $\beta, \beta$-carotene) are used in salmonid feed. However, astaxanthin, the natural carotenoid of wild salmonid, is better deposited than canthaxanthin in the muscle of salmonids (Foss et al., 1984; Torrissen, 1986; Choubert and Storcbakken, 1989; Torrissen, 1989; Bjerkeng et al., 1990; No and Storebakken, 1992).

Scxual maturation of salmonids involves significant changes in their metabolism, particularly in carotenoids (reviewed by Choubert, 1986). Wild salmonids stop feeding during anadromous spawning migration. Compared to immature fish, spawning fish have lower carotenoid concentrations in the muscle which may be explained by internal redistribution of carotenoids: astaxanthin would be mobilized from the muscle and accumulated in remales in the ripening eggs, and in males in the skin (Steven, 1949; Crozier, 1970; Shnarevitch and Sakhnenko, 1971; Kitahara, 1983; Ando, 1986). Farmed salmonids are regularly fed during spawning season, although at a slightly lower rate. Muscular pigmentation of fomale trout has been shown to increase throughout the spawning season with dictary canthaxanthin at a level as high as $200 \mathrm{mg} / \mathrm{kg}$ diet (Choubert and Blanc, 1989). For males, no such data are available in the literature.

The objective of this study was to investigate the changes in pigment concentrations in the muscle of rainbow trout of both sexes, continuously fed astaxanthin-or canthaxanthin-supplemented diets, associated with spawning and post-spawning recovery. Colour of trout muscle was also investigated.

\section{MATERIAL AND METHODS}

\section{Experimental conditions}

The experiment was conducted in the INRA experimental fish farm of Lées-Athas (South-west of France). Four groups of 200 rainbow trout, Oncorhynchus mykiss (Walbaum), aged $2+$ with an initial weight of $600 \mathrm{~g}$ werc grown with 4 different diets in 4 separates $35 \mathrm{~m}^{2}$ gravel bottom ponds. The water was taken from a mountain spring, having a constant temperature of $8^{\circ} \mathrm{C}\left( \pm 1^{\circ} \mathrm{C}\right)$. Its $\mathrm{pH}$ was $7-8$ and it was saturated with oxygen (10 to $12 \mathrm{mg} \mathrm{O} / 1$ ). The experimental period lasted 11 months, beginning
30) weeks before spawning and ending 18 weeks after spawning.

\section{Fecd and feeding}

Fish were fed a commercially available dry pelleted diet without carotenoid (proximate analysis: $49.2 \%$ crude protein, $8.7 \%$ crude fat and $1.15 \mathrm{~kJ} / \mathrm{g}$ energy) as control (CTL). Astaxanthin or canthaxanthin was added as gelatin stabilized beadlets (HoffmannLa Roche and Co, Basel, Switzerland) so as to obtain three expcrimental diets: $\triangle 50$ and $A 100=$ control dict supplemented with 50 and $100 \mathrm{mg}$ astaxanthin $/ \mathrm{kg}$ diet respectively and $C 10()=$ control dict supplemented with $100 \mathrm{mg}$ canthaxanthin $/ \mathrm{kg}$ dict. The analyzed carotenoid contents of the diets were, on a dry weight basis, $C T L=0 \mathrm{mg} / \mathrm{kg}, \mathrm{A} 50=49.1 \mathrm{mg}$ astaxanthin $/ \mathrm{kg}$ diet, $\quad$ A $100=107.1 \mathrm{mg}$ astaxanthin $/ \mathrm{kg}$ diet and C $100=97.4 \mathrm{mg}$ canthaxanthin $/ \mathrm{kg}$ dict. All diets were stored at $+4^{\circ} \mathrm{C}$ during the experiment. The fish were fed to apparent satiation twice a day during the 11 month experimental period.

\section{Analytical methods}

Five sampling operations were performed: ten wceks before spawing, at spawning, and 4, 8 and 18 weeks after spawning. At each sampling, muscles from 5 troul of each sex per group were removed. One fillet from each fish was used for visual rank evaluation and physical colourimetric measurement. The other fillet was kept at $-80^{\circ} \mathrm{C}$ until carotenoid analysis.

Carotenoid analysis was carried on pooled samples of each sex within each experimental group. Muscles were blended for $30 \mathrm{~s}$ at maximum speed (approx. $1500 \mathrm{r}$. per min). After acctone extraction, astaxanthin and canthaxanthin analysis were performed with an isocratic reverse phase high pressure liquid chromatography (RPHPLC) method (Guillou et al., 1993). Carotenoid amounts were expressed on a dry basis using extinction coefficients (E $1 \% 1 \mathrm{~cm}$ ) of 2100 for astaxanthin and 2200 for canthaxanthin, both at their absorption maximum in hexane (De Ritter and Purcell, 1981). One pigment extract was made from each sample, with two replicate carotenoid determinations from each pigment extract. Homogenates of the muscle samples from the fish selected for processing and colour analysis were analyzed for dry matter at $105^{\circ} \mathrm{C}$ overnight.

Colour of individual chopped muscle was measured according to Wyszecki and Stiles (1967) through the mouth of the cap on a colour analyser (Gardner LX 20, aperture $8 \mathrm{~mm}$ ) calibrated with a white plate reference standard before each sample. Reflected light values were obtained by avcraging four readings, the sample being rotated 90 degrees between each measurement (Schmidt and Cuthbert, 1969). From the redness $(a)$ and yellowness $(b)$ intensity values, the 


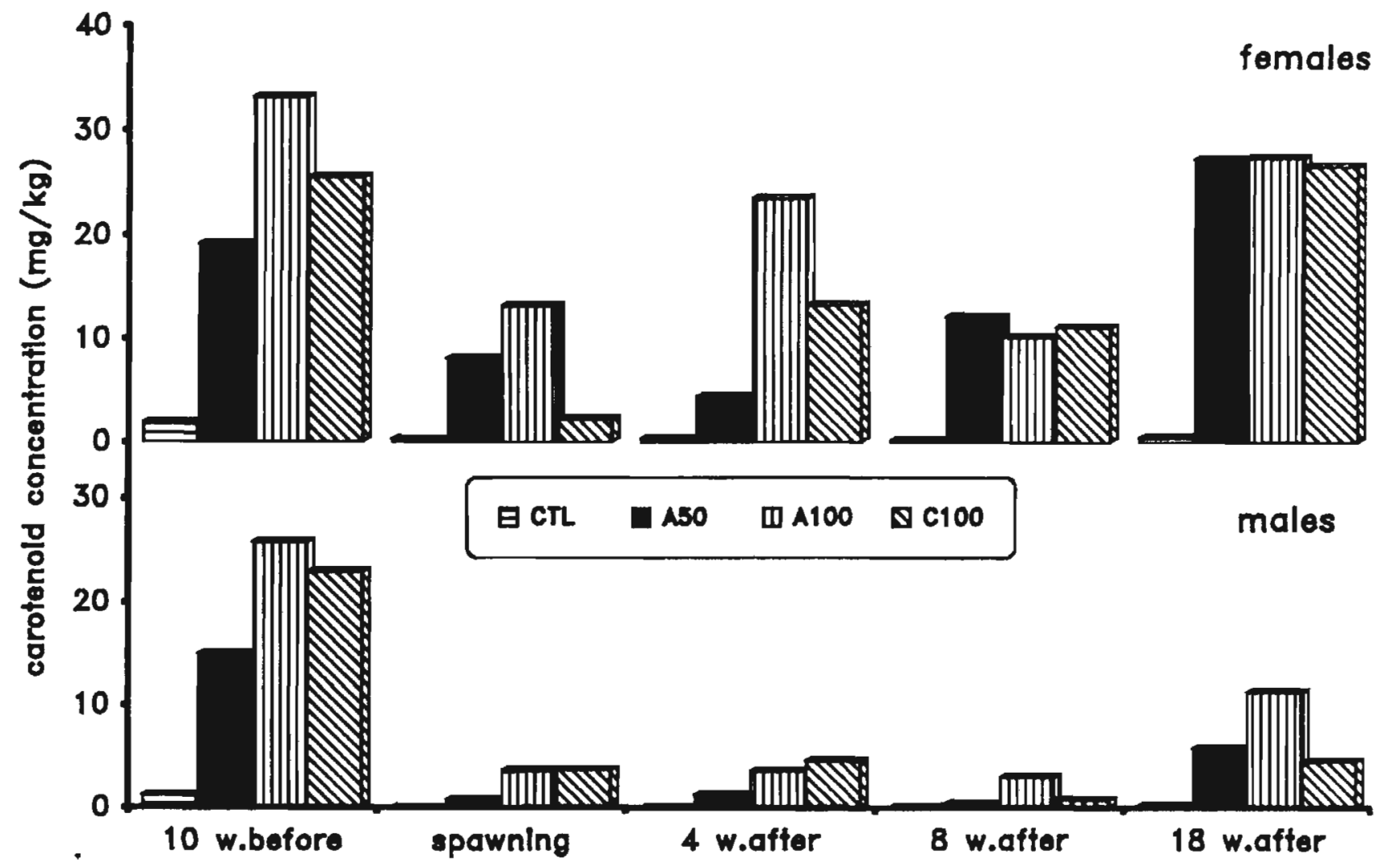

Figure 1. - Changes in muscle carotenoid concentrations associated with spawning and post-spawning recovery in male and female rainbow trout.

huc was calculated as $100 \mathrm{a} / \mathrm{h}$, according to Wyzecki and Stiles (1967).

Visual evaluation was performed immediately after each sampling operation by ranking, under natural (outdoor) light, the 40 fillets from the lowest (rank 1) to the highest (rank 40) intensity of colour. Therefore, the evaluation for one lish was relative to each other fish within sampling dates and did not allow comparisons among successive samplings.

Data on pigment concentration and colourimetry were processed through analysis of variance and means were compared using the Newman and Keuls test (Snedecor and Cochran, 1967). Visual rank data were processed using the Mann and Whitney test (Snedecor and Cochran, 1967).

\section{RESUITS}

After a period of active growth, with a mean growth rate (\% per week) of 3.54 , sexual maturation caused a decrease of growth in both sexes, down to a mean rate of 0.43 . After spawning, the growth rate improved in females (1.53), while remaining at a significantly $(p<0.05)$ lower level in males $(0.53)$.
The changes in muscle carotenoid concentrations associated with spawning and post-spawning recovery were different in male and female rainbow trout (fig. 1). Ten weeks before spawning, the major and highly significant $(p<0.05)$ effects were those of carotenoid supplementation to diet: muscle carotenoid content increased with increased carotenoid in the diet (A 100 vs A 50). At spawning, muscle carotenoid concentrations decreased in both sexes, and particularly in males. During the next four months, spawned females progressively recovered muscle carotenoid concentrations equivalent to those observed before spawning; in contrast, males recovered only one third of their initial muscle carotenoid concentrations. Compared to that large sexual difference, variation among groups fed supplemented diets appeared to be of little importance.

Average colour parameters $(100 a / b)$ were calculated from the reflectance spectra of muscle of the individuals subjected for processing (table 1). Increasing muscle carotenoid concentrations caused significan1ly increased redness and gave a more reddish hue to the muscle. After spawning, redness decreased with decreasing pigment concentration. Muscles from astaxanthin fed fish (A 100) remained more red than 
Table 1. - Colourimetric measurement $(100 a / b)$ calculated from the reflectance spectra of rainbow trout muscle fed diets supplemented with synthetic carotenoids (mean \pm standard error, $n=5$ ).

\begin{tabular}{lrrr} 
& Males & \multicolumn{1}{c}{ Females } \\
10 wecks before spawning & \\
CTL & $57.8 \pm 3.0$ & $53.2 \pm 2.6$ \\
A 50 & $87.6 \pm 6.0$ & $101.0 \pm 4.8$ \\
A 100 & $115.4 \pm 6.1$ & $119.6 \pm 4.4$ \\
C 100 & $90.8 \pm 4.1$ & $94.0 \pm 3.6$ \\
4 weeks after spawning & \\
CTL & $58.8 \pm 4.0$ & $42.4 \pm 3.8$ \\
A 50 & $59.6 \pm 5.6$ & $59.4 \pm 9.6$ \\
A 100 & $74.0 \pm 8.6$ & $90.6 \pm 11.3$ \\
C 100 & $71.6 \pm 7.3$ & $74.6 \pm 10.5$ \\
8 weeks after spawning & \\
CTL & $48.6 \pm 5.0$ & $40.6 \pm 1.9$ \\
A 50 & $57.0 \pm 5.5$ & $86.2 \pm 5.7$ \\
A 100 & $68.4 \pm 5.1$ & $78.2 \pm 5.6$ \\
C 100 & $58.6 \pm 3.6$ & $68.6 \pm 8.8$ \\
18 weeks after spawning & \\
CTL & $49.8 \pm 7.1$ & $42.2 \pm 4.4$ \\
A 50 & $70.8 \pm 4.5$ & $108.6 \pm 4.4$ \\
A 100 & $84.4 \pm 10.6$ & $112.0 \pm 4.0$ \\
C 100 & $62.6 \pm 3.5$ & $92.6 \pm 3.0$ \\
\hline
\end{tabular}

(') $\mathrm{CTL}=$ control; A 50 and A 100= control diet supplemented with astaxanthin $50 \mathrm{mg} / \mathrm{kg}$ and $100 \mathrm{mg} / \mathrm{kg}$ respectively; $\mathrm{C} 100=$ control diet supplemented with $100 \mathrm{mg} / \mathrm{kg}$ canthaxanthin.

those from canthaxanthin fed fish (C 100). Moreover, females recovered their muscle colour within 18 weeks after spawning.

In the rank test, comparison of trout muscle with different astaxanthin or canthaxanthin concentrations revealed significant $(p<0.05)$ visual difference for males and females within sampling dates (table 2). Astaxanthin (A 100) caused higher rank values of the trout muscle than canthaxanthin at equal feed pigment concentration (C 100) until spawning.

Correlations analysis between the three methods of pigmentation of trout muscle measurement (table 3) showed significant within-sampling correlations between: 1) chemical analysis and colourimetric measurements $(r=0.90)$; 2) chemical analysis and visual rank evaluation $(r=0.91)$ and 3$)$ colourimetric measurements and visual rank evaluation $(r=0.86)$. These correlations remained fairly constant throughout the experiment.

\section{DISCUSSION}

Three different methods were used to appreciate the muscle pigmentation of trout: the chemical analysis and the colour measurement, which are two objective methods, and the rank test which is a subjective method. Sensory analyses have been performed on fish using different systems: the natural colour system (NCS) (SSI, 1979; Skrede and Storebakken, 1986); the Roche (Roche vitamins and fine chemicals division,
Table 2. - Visual rank evaluation of rainbow trout muscle fed dicts supplemented with synthetic carotcnoids (mcan \pm standard error, $n=5$ ).

\begin{tabular}{lrr} 
& Males & Females \\
\cline { 2 - 3 } 10 weeks before spawning & \\
CTL & $4.0 \pm 1.2$ & $7.0 \pm 1.2$ \\
A 50 & $17.2 \pm 2.8$ & $21.4 \pm 3.9$ \\
A 100 & $30.2 \pm 2.9$ & $36.0 \pm 1.4$ \\
C 100 & $26.4 \pm 3.9$ & $21.8 \pm 2.5$ \\
Spawning & & \\
CTL & $9.4 \pm 1.6$ & $7.6 \pm 2.9$ \\
A 50 & $16.6 \pm 3.3$ & $34.2 \pm 2.2$ \\
A 100 & $25.6 \pm 2.4$ & $35.4 \pm 1.9$ \\
C 100 & $17.0 \pm 5.0$ & $18.2 \pm 4.1$ \\
4 weeks after spawning & \\
CTL & $6.6+1.1$ & $9.4 \pm 3.6$ \\
A 50 & $13.2 \pm 3.6$ & $25.8 \pm 3.0$ \\
A 100 & $19.0 \pm 3.9$ & $34.8 \pm 2.2$ \\
C 100 & $23.4 \pm 3.7$ & $31.8 \pm 3.4$ \\
8 weeks after spawning & \\
CTL & $5.2 \pm 1.2$ & $6.2 \pm 1.8$ \\
A 50 & $16.8 \pm 1.4$ & $33.6 \pm 2.1$ \\
A 100 & $24.4 \pm 2.0$ & $33.6 \pm 2.5$ \\
C 100 & $14.6 \pm 2.1$ & $29.6 \pm 2.9$ \\
18 weeks after spawning & \\
CTL & $4.4 \pm 1.3$ & $10.4 \pm 1.9$ \\
A 50 & $17.6 \pm 1.2$ & $33.8 \pm 2.5$ \\
A 100 & $17.6 \pm 4.6$ & $34.4 \pm 2.7$ \\
C 100 & $15.8 \pm 3.0$ & $30.0 \pm 0.7$ \\
\hline & &
\end{tabular}

( $\left.{ }^{1}\right)$ CTL $=$ control; A 50 and A $100=$ control diet supplemented with astaxanthin $50 \mathrm{mg} / \mathrm{kg}$ and $100 \mathrm{mg} / \mathrm{kg}$ respectively; $\mathrm{C} 100=$ control dict supplemented with $100 \mathrm{mg} / \mathrm{kg}$ canthaxanthin.

Table 3. - Correlation coefficients between the three methods of muscle pigmentation measurements used (calculated from the means for each sex in each carotenoid-supplemented batches, $n=6$ ).

\begin{tabular}{llll}
\hline & $\mathrm{P} / \mathrm{C}^{1}$ & $\mathrm{P} / \mathrm{R}$ & $\mathrm{C} / \mathrm{R}$ \\
\hline 10 weeks before spawning & $0.84^{* 2}$ & $0.94^{* *}$ & $0.86^{*}$ \\
Spawning & & $0.90^{*}$ & \\
4 weeks after spawning & $0.89^{*}$ & $0.88^{*}$ & 0.74 \\
8 weeks after spawning & $0.91^{*}$ & $0.95^{* *}$ & $0.94^{* *}$ \\
18 weeks after spawning & $0.95^{* *}$ & $0.98^{* *}$ & $0.93^{* *}$ \\
\hline
\end{tabular}

$\left({ }^{1}\right)$ P: Chemical analysis; C: colourimetric measurement; R: visual rank evaluation.

$\left({ }^{2}\right)$ Significance level: ${ }^{*} p=0.05 ;{ }^{* *} p=0.01$.

Hoffmann-La Roche Inc., Nutley, USA) colour card for salmon (Skrede et al., 1990; Smith et al., 1992); or an arbitrarly flesh colour scale with values of 1 (no visual pigmentation) to 8 (maximum red) (Foss et al., 1984; Aksnes et al., 1986; Foss et al., 1987; McCallum et al., 1987; Sommer et al., 1991). However, due to the inherent variability that occurs when measuring muscle pigmentation of fish using colour card (Skrede et al., 1990; Smith et al., 1992) the value of comparing results from one study with those of another is limited. Despite the influencing factors which control visual scoring, some observations are 
worth mentioning. The rank test used in this experiment was the same as that used in poultry (Chemillier, 1977) and remains more precise than the other sensory evaluations, when colour differences are slight. However, this method does not allow comparison of samples collected at different times. In our experiment, the three methods (chemical analysis, colour measurement and rank test) were correlated satisfactorily within sampling operations. This is in agreement with previous findings showing relationship between sensory and instrumentally assessed colour in rainbow trout (Skrede et al., 1990), instrumentally assessed colour and carotenoid concentration in rainbow trout (Choubert, 1982; Skrede et al., 1990) or sensory and carotenoid concentration in coho salmon Oncorhynchus kisutch (Smith et al., 1992).

A better deposition of astaxanthin over canthaxanthin in the muscle of salmonids has been reported (Foss et al., 1984; Torrissen, 1986; Choubert and Storebakken, 1989; Torrissen, 1989; Bjerkeng et al., 1990; No and Storebakken, 1992). In our experiment no significant differences were observed in pigment deposition in the muscle between fish fed synthetic astaxanthin and synthetic canthaxanthin. These contradictory results were similar to previous findings in rainbow trout and sea trout Salmo trutta (L.) (Foss et al., 1987) or Atlantic salmon Salmo salar (L). (Storebakken et al., 1987). The deposition mechanisms for the individual carotenoids in salmonids are not well known and are probably complex.

Carotenoid concentrations of rainbow trout muscle significantly decreased when fish became sexually mature (lowest concentrations were reached at spawning) despite the fact that fish were fed over this period. In the wild such a phenomenom is known since the fish feeding activity is reduced or even interrupted (anadromous migrating salmon): wild salmonids undergoing sexual maturation mobilize carotenoids from the flesh and selectively transfer them to the skin and gonads (Steven, 1949; Crozier, 1970; Shnarevitch and Sakhnenko, 1971; Kitahara, 1983; Ando,
1986). For farmed fish the pattern is somewhat different as fish are regularly fed even at a lower rate. It has been reported that the total amount of dietary canthaxanthin would be allocated about equally to muscle and ovary in rainbow trout (Choubert and Blanc, 1989) like astaxanthin in Atlantic salmon (Torrissen and Torrissen, 1985). Therefore the decrease in canthaxanthin concentration in female muscle was in contrast with previous findings (Choubert and Blanc, 1989) and may be due to the lower dietary canthaxanthin level (100 vs 200 canthaxanthin $/ \mathrm{kg}$ diet). The decrease of growth rate in both sexes at spawning would also explain this finding. However, this does not appear enough, by itself, to explain the depigmentation since, in immature trout, the depletion of canthaxanthin during starvation was found to be a very slow process (Choubert, 1985). Another explanation would be the increasing metabolism of carotenoids to vitamin $\mathrm{A}$ in the mature fish (Al-Khalifa and Simpson, 1988; Guillou et al., 1989) but it concerns only astaxanthin since no conversion from canthaxanthin to vitamin $\mathrm{A}$ has been reported.

Females recovered their muscle carotenoid concentrations after spawning. In males, the recovery was slower, which might be explained by the fact that males are mature earlier and remain so over a longer period than the females (Sano, 1960; Aksness et al., 1986). This is corroborated by comparison of the growth rates in the present experiment.

In usual fish farming practice, sexually mature individuals are not marketed, since a significant alteration of the flesh composition and concomitant deterioration of the flesh quality occur (Torrissen and Torrissen, 1985; Aksnes et al., 1986). The use of high carotenoid levels (as high as $100 \mathrm{mg}$ carotenoid/ $\mathrm{kg}$ diet) in the diet of rainbow trout prior to spawning did not prevent the depletion of carotenoids from the flesh, as was reported for Atlantic salmon (Helland et al., 1990). Therefore, the fish producer should avoid providing dietary carotenoids to fish, at least to males, in this biological condition.

\section{Acknowledgements}

The authors wish to thank Laurence Larroquet, F. Vallee and Jacqueline Vasseur (Produits Roche s.a., 59, rue Pasteur, 94120 Fontenay-sous-Bois, France) for their technical assistance and L. Casenave for maintenance of the experimental animals. The authors thank also J. Chemillier (Produits Roche s.a., 52, bd du Parc, 92521 Neuilly-sur-Seine cedex, France), J.-P. Belliot (Produits Roche s.a., 59, rue Pasteur, 94120 Fontenay-sous-Bois, France), K. Streiff and T. Latscha (F. Hoffman-La Roche \& co, 4002 Basel, Switzerland) for their interest.

\section{REFERENCES}

Al-Khalifa A. S., K. L. Simpson, 1988. Metabolism of astaxanthin in the rainbow trout (Salmo gairdneri). Comp. Biochem. Physiol., 91 B, 563-568.
Aksnes A., B. Gjerde, S. O. Roald, 1986. Biological, chemical and organoleptic changes during maturation of farmed Atlantic salmon, Salmo salar. Aquaculture, 53, 7-20.

Ando S., 1986. Studies on the food biochemical aspects of changes in Chum salmon (Oncorhynchus keta) during spawning migration: mechanism of muscle deterioration 
and nuptial coloration. J. Fac. Fish. Jlokkaido Uniz., 33, $1-95$.

Bjerkeng B., T. Storcbakken, S. Liaaen-Jensen, 1990. Dose response to carotenoids by rainbow trout in the sca: resorption and metabolism of dietary astaxanthin and canthaxanthin. Aquaculture, 91, 153-162.

Chemillier J., 1977. La pigmentation du poulet de chair. Doc. ROCIIE, 1393, 1-35.

Choubert G., 1982. Method for colour assessment of canthaxanthin pigmented rainbow trout (Salmo gairdneri Rich.). Sci. Aliments, 2, 451-463.

Choubert G., 1985. Effects of starvation and feeding on canthaxanthin depletion in the muscle of rainbow trout (Salmo gairdneri Rich.). Aquaculture, 46, 293-298.

Choubert G., 1986. Pigments caroténoïdes ct reproduction des poissons. Bull. Fr. Péche Piscic., 300, 25-32.

Choubert G., J.-M. Blanc, 1989. Dynamics of dietary canthaxanthin utilization in sexually maturing female rainbow trout (Salmo gairdneri Rich.) compared to triploids. Aquaculture, 83, 359-366.

Choubert G., T. Storebakken, 1989. Dose response to astaxanthin and canthaxanthin pigmentation of rainbow trout fed various dietary carolenoid concentrations. Aquaculture, 81, 69-77.

Crozier G. F., 1970. Tissuc carotenoids in prespawning and spawning sockeye salmon (Oncorhynchus nerka). J. Fïsh. Res. Board Can., 27, 973-975.

De Ritter E., A. E. Purcell, 1981. Carotenoid analytical methods. In: Carotenoids as Colorants and Vitamin A Precursors, J. C. Baucrnfeind ed., Academic press, New York, 815-923.

Foss P., T. Storebakken, K. Schicdt, S. Liaaen-Jensen, E. Austreng, K. Streiff, 1984. Carotcnoids in diets for salmonids. I. Pigmentation of rainbow trout with the individual optical isomers of astaxanthin in comparison with canthaxanthin. Aquaculture, 42, 213-226.

Foss P., T. Storebakken, E. Austreng, S. Liaaen-Jensen, 1987. Carotenoids in dicts for salmonids. V. Pigmentation of rainbow trout and sea trout with astaxanthin and astaxanthin dipalmitate in comparison with canthaxanthin. Aquaculture, 65, 293-305.

Guillou A., G. Choubert, J. de la Noüe, 1993. Separation and determination of carotenoids, retinol, retinal and their dehydro forms by an isocratic reversed-phase HPLC method. Food Chem., 47, 93-99.

Guillou A., G. Choubert, T. Storebakken, J. de la Noüe, 1989. Bioconversion pathway of astaxanthin into retinol ${ }_{2}$ in mature rainbow trout (Sulmo gardneri Rich.). Comp. Biochem. Physiol., 94 B, 481-485.

Helland S., B. Grisdale-Helland, H. K. No, T. Storebakken, 1990. Effect of previous pigmentation on carotenoid accumulation in rainbow trout. 9 th Int. Symp. on Carotenoids, Kyoto, Japan, 20-25 May 1990, p. 117.
Kitahara T., 1983. Behaviour of carotenoids in the chum salmon (Oncorhynchus keta) during anadromous migration. Comp. Biochem. Physiol. 76 B, 97-101.

McCallum I. M., K. M. Cheng. B. E. March, 1987. Carotenoid pigmentation in two strains of chinook salmon (Oncorhynchus tshanytscha) and their crosses. Aquaculture, 67, 291-300).

No H. K.. T. Storebakken, 1992. Pigmentation of rainbow trout with astaxanthin and canthaxanthin in freshwater and saltwater. Aquaculture, 101, 123-134.

Sano T., 1960. Hacmatological studies of the culture fish in Japan. Changes in blood constituents with growth of rainbow trout. J. Tokyo Uniz. Fish., 46. 77-87.

Schmidt P. J., R. M. Cuthbert, 1969. Color sorting of raw salmon. Food Technol.. 23, 98-100).

Shnarevich I. D., E. G. Sakhnenko, 1971. Dynamies of carotenoids in tissues and organs of fish relative to the sexual cycle. Gidrohiol. Zh., 7, 9()-93.

Skrede G., E. Risuik, M. Huber, G. Enersen, L. Blümlein, 1990. Develoning a color card for raw llesh of astaxanthin-fed salmon. J. Food Sci., 55, 361-363.

Skrede G., T. Storebakken, 1986. Charactcristics of color in raw, baked and smoked wild and pen-reared Atlantic salmon. J. Fond Sci., 51, 804-808.

Smith B. E., R. W. Hardy, O. J. Torrissen, 1992. Synthetic astaxanthin deposition in pan-size coho salmon (Oncorhynchus kisutch). Aquaculture, 104, 105-119.

Snedecor G. W., W. G. Cochran, 1967. Statistical methods. The Iowa State Univ. Press., Ames, U.S.A., 507 p.

Sommer T. R., W. T. Potts, N. M. Morrissy, 1991. Utilization of microalgal astaxanthin by rainbow trout (Oncorhynchus mykiss). Aquaculture, 94, 79-88.

SSI, 1979. "Color Atlas". Swedish Standard SS019102. Swedish standard institution. Box 3295. S-10366-Stockholm, Sweden.

Steven D. M., 1949. Studies on animal carotenoids. II. Carotenoids in the reproductive cycle of the brown trout. J. Exp. Biol., 26, 295-303.

Storcbakken T., P. Foss, K. Schiedt, E. Austreng, S. Liaaen-Jensen, U. Mantz, 1987. Carotenoids in diets for salmonids. IV. Pigmentation of Atlantic salmon with astaxanthin, astaxanthin dipalmitate and canthaxanthin. Aquaculture, 65, 279-292.

Torrissen O. J., 1986. Pigmentation of salmonids - a comparison of astaxanthin and canthaxanthin as pigment sources for rainbow trout. Aquaculture, 53, 271-278.

Torrissen O. J., 1989. Pigmentation of salmonids. Interactions of astaxanthin and canthaxanthin on pigment deposition in rainbow trout. Aquaculture, 79, 363-374.

Torrissen K. R., O. J. Torrissen, 1985. Protease activities and carotenoid levels during the sexual maturation of Atlantic salmon (Salmo salar). Aquaculture, 50, 113-122.

Wyszecki G., W. S. Stiles, 1967. Color Science. John Wiley and Sons, New York, U.S.A., 628 p. 